JURNAL KETAHANAN NASIONAL

Vol. 26, No. 1, April 2020, Hal 87-107

DOI:http://dx.doi.org/ 10.22146/jkn.53816

ISSN:0853-9340(Print), ISSN:2527-9688(Online)

Online sejak 28 Desember 2015 di :http://jurnal.ugm.ac.id/JKN

VOLUME 26

No. 1, April 2020

Halaman 87-107

\title{
Penguatan Kewarganegaraan Ekologis Untuk Mewujudkan Ketahanan Lingkungan \\ (Studi di Kampung Gambiran, Kelurahan Pandeyan, Kecamatan \\ Umbulharjo, Kota Yogyakarta, Daerah Istimewa Yogyakarta)
}

\author{
Serlina Candra Wardina Sari \\ Universitas Negeri Yogyakarta, Indonesia \\ email: serlinacandra.2018@student.uny.ac.id \\ Samsuri \\ Universitas Negeri Yogyakarta, Indonesia \\ email: samsuri@uny.ac.id \\ Darto Wahidin \\ Pusat Studi Ketahanan Nasional, Indonesia \\ email: dartowahidin2@gmail.com
}

\begin{abstract}
The idea of ecological citizenship is present and has important implications on the conception of citizenship in the field of environmental preservation. The purpose of this study is to analyze the strengthening of ecological citizenship to realize environmental resilience through environmental awareness programs in Gambiran village as the Green Village of Yogyakarta City.

This research uses a qualitative approach with a case study design. Data collection uses observation, interview, and documentation techniques. Data analysis uses interactive analysis techniques consisting of data reduction, data presentation, and data verification.

The results showed that strengthening ecological citizenship to realize environmental resilience consisted of: management of the Gajah Wong river, tree planting, independent waste management, IPAL communal, green space, krida parks and cross-cultural parks, libraries and wi-fi parks, and the use of alternative energy. The results of ecological citizenship as a form of environmental resilience have a positive impact on several fields: environmental, social, and economic. Challenges and obstacles in the development of the Green Village of Yogyakarta City lies in the community's concern that sometimes fluctuates and the role of youth is still lacking so that it inhibits the regeneration process. Synergy between the community and the government must be open and interactive in realizing environmental resilience in Gambiran village.
\end{abstract}

Keywords: Ecological Citizenship, Environmental Resilience, Green Village.

\begin{abstract}
ABSTRAK
Gagasan kewarganegaraan ekologis hadir dan membawa implikasi penting pada konsepsi kewarganegaraan dalam bidang pelestarian lingkungan. Tujuan penelitian ini adalah menganalisis penguatan kewarganegaraan ekologis untuk mewujudkan ketahanan lingkungan melalui program-program kepedulian lingkungan di Kampung Gambiran sebagai Kampung Hijau Kota Yogyakarta.
\end{abstract}


Penelitian ini menggunakan pendekatan kualitatif dengan desain studi kasus. Pengumpulan data menggunakan teknik observasi, wawancara, dan dokumentasi. Analisis data menggunakan teknik analisis interaktif yang terdiri dari reduksi data, penyajian data, dan verifikasi data.

Hasil penelitian menunjukkan bahwa penguatan kewarganegaraan ekologis untuk mewujudkan ketahanan lingkungan terdiri dari: pengelolaan sungai Gajah Wong, tanam pohon, pengelolaan sampah mandiri, IPAL komunal, RTH, taman krida dan taman lintas budaya, perpustakaan dan taman wifi, serta penggunaan energi alternatif. Hasil dari kewarganegaraan ekologis sebagai wujud ketahanan lingkungan membawa dampak positif pada beberapa bidang, yakni: lingkungan, sosial, dan ekonomi. Tantangan dan hambatan dalam pengembangan Kampung Hijau Kota Yogyakarta terletak pada kepedulian masyarakat yang terkadang naik turun dan peran pemuda yang masih kurang sehingga menghambat proses regenerasi. Sinergi antara masyarakat dan pemerintah harus secara terbuka dan interaktif dalam mewujudkan ketahanan lingkungan di Kampung Gambiran.

\section{Kata Kunci: Kewarganegaraan Ekologis, Ketahanan Lingkungan, Kampung Hijau.}

\section{PENGANTAR}

Warga negara memiliki hak dan kewajiban dalam pelestarian alam dan lingkungan (Prasetyo \& Dasim, 2016). Pelestarian alam dan lingkungan menjadi hal penting karena manusia mengambil sumber daya alam guna menunjang kelangsungan hidup secara berkelanjutan (Mariyani, 2017; Jannah, 2018). Relasi organisme dan lingkungan saling menentukan yang terkait dengan perubahan material dan material tersebut menjadi relasi itu sendiri (Foster, 2013: 261). Hubungan antara perilaku warga negara dengan krisis ekologi yang mencerminkan kurangnya kesadaran warga negara terhadap pelestarian lingkungan ditunjukkan oleh Yuniarto (2011: 9) bahwa kerusakan lingkungan selain disebabkan oleh faktor alam, juga disebabkan oleh rendahnya kesadaran warga negara dalam upaya pelestarian lingkungan guna keberlangsungan hidup pada masa sekarang dan masa yang akan datang. Bukti-bukti yang banyak tersebar luas dalam kehidupan sehari-hari seperti pembuangan sampah sembarangan, penebangan pohon secara liar (illegal logging), dan pembangunan antara sektor fisik dan upaya pelestarian lingkungan menunjukkan kondisi yang timpang (Prasetyo \& Dasim, 2016; Pertiwi \& Samsuri, 2017). Kerusakan lingkungan yang terjadi di abad sekarang merupakan bencana global (global catastrope) jika melihat dari luasnya dampak yang ditimbulkan hingga melewati batas territorial (Nagra, 2010). Pada konteks ini, program-program yang mengarah pada dukungan pelestarian lingkungan perlu diberikan moralitas kepedulian lingkungan sebagai bentuk pencegahan terhadap kejahatan ekologi (Budimansyah, 2015).

Ekologi berhubungan erat dengan tingkatan-tingkatan organisasi makhluk hidup, yaitu: populasi, komunitas, dan ekosistem yang saling memengaruhi satu sama lain sebagai suatu sistem yang menunjukkan kesatuan. Ekologi mempelajari bagaimana makhluk hidup dapat mempertahankan kehidupannya dengan mengadakan hubungan antar makhluk hidup dan benda mati di dalam tempat hidupnya atau lingkungannya (Napitupulu, Achmad, Sri, \& Bayong, 2018). Manusia harus belajar dan memahami lingkungan serta pandai mengatur pemakaian sumber-sumber daya alam dengan cara-cara yang dapat dipertanggung jawabkan demi pengamanan dan kelestarian lingkungan secara berkelanjutan (Irwan, 2017: 12). Hal ini berkaitan dengan konsep kewarganegaraan ekologis bahwa masyarakat sebagai warga negara harus menjaga dan melestarikan lingkungan. Tidak hanya mengambil untuk kebutuhan hidup 
Serlina Candra Wardina Sari, Samsuri, Darto Wahidin -- Penguatan Kewarganegaraan Ekologis Untuk Mewujudkan Ketahanan Lingkungan (Studi di Kampung Gambiran, Kelurahan Pandeyan, Kecamatan

Umbulharjo, Kota Yogyakarta, Daerah Istimewa Yogyakarta)

jangka pendek namun juga harus dijaga dan dilestarikan demi kelangsungan hidup jangka panjang. Gagasan kewarganegaraan ekologis hadir dan membawa implikasi penting pada konsepsi kewarganegaraan yang berhubungan dengan keberadaan di dunia pada saat ini sebagai masyarakat resiko. Masyarakat resiko dan lingkungan memunculkan kesadaran baru di dalam masyarakat bahwa manusia hidup dalam zaman yang ditandai oleh ketidakpastian dan bahaya yang relatif lebih sering dan lebih tinggi (Kalidjernih, 2011: 155).

Usaha untuk melindungi masyarakat dari hasil kerusakan lingkungan karena kegiatan dan aktivitas yang tidak ramah lingkungan menuntut kepedulian terhadap pelestarian daya dukung lingkungan, mencegah eksploitasi terhadap lingkungan, dan mendorong pertanggung jawaban terhadap sumber-sumber alam sebagai investasi jangka panjang secara berkelanjutan (Kalidjernih, 2011: 156). Tanggung jawab manusia bukan hanya terhadap manusia, tapi juga alam. Pandangan tersebut menegaskan bahwa dalam perkembangannya pada era modern terjadi perubahan pada alam dan lingkungan yang berpengaruh pada kelangsungan hidup manusia. Hal ini memunculkan kesadaran untuk melakukan gerakan-gerakan secara bersama dan bersinergi dalam memelihara alam dan lingkungan yang berlandaskan hak dan kewajiban sebagai warga negara yang baik (good citizen). Oleh karena itu, penting untuk pengembangan diri dalam mengatasi bencana yang terjadi untuk mewujudkan ketahanan lingkungan secara berkelanjutan.

Gerakan kewarganegaraan ekologis mengenai pemeliharaan sumber daya alam diwujudkan dalam bentuk aturan-aturan yang mengatur ketersediaan, pengelolaan, dan pemanfaatan sumber daya alam. Kota
Yogyakarta turut mengalami masalah dalam pengelolaan dan pelestarian lingkungan hidup. Data dari Rancangan Pembangunan Jangka Menengah Daerah (RPJMD) periode 2017-2022 pada Peraturan Daerah Kota Yogyakarta Nomor 11 Tahun 2017 tercatat bahwa persoalan lingkungan di Kota Yogyakarta terutama pada penanganan sampah, distribusi air bersih, dan pencemaran sungai harus mendapatkan perhatian lebih. Pada tahun 2012, volume sampah yang diangkut mencapai $68,44 \%$. Hal ini memiliki arti bahwa hampir sepertiga sampah yang diperkirakan ada di Kota Yogyakarta tidak diangkut ke TPA (Tempat Pembuangan Akhir). Sisa sampah tersebut diperkirakan diolah oleh masyarakat sendiri, dibuang ke sungai, dibuang ke lahan kosong, atau dibiarkan di pinggir jalan. Data menunjukkan bahwa dalam kurun waktu tahun 2012 sampai tahun 2016, volume sampah yang diolah atau dimanfaatkan kembali cenderung menurun. Pada tahun 2012 volume sampah yang diolah mencapai 70 ton/ hari, namun kemudian berangsur menurun pada tahun berikutnya menjadi 57 ton/ hari pada tahun 2013, 54 ton/hari pada tahun 2014, menjadi 52,17 ton/hari pada tahun 2015, dan pada tahun 2016 kembali menurun menjadi hanya 45,28 ton/hari. Akses air bersih atau air minum juga menjadi permasalahan, penduduk yang belum mendapatkan pelayanan air minum setiap tahunnya semakin bertambah. Pada tahun 2012, persentase cakupan pelayanan air minum mencapai $46,41 \%$, jumlah ini terus mengalami penurunan, hingga pada tahun 2016 persentasenya menjadi 43,02\%. Penurunan persentase cakupan pelayanan air minum mencapai $0,85 \%$ per tahun. Oleh karena itu, diperlukan perhatian khusus terkait dengan pengembangan pelayanan air minum. 
Berdasarkan RPJMD Kota Yogyakarta periode 2017-2022 bahwa kondisi air sungai pada tahun 2012 terdapat 72 sampel yang memenuhi parameter baku mutu dari sebanyak 100 sampel sehingga persentase kualitas air sungai yang sesuai baku mutu sebesar $72 \%$. Pada tahun 2013 tercatat sebanyak 74 sampel memenuhi parameter baku mutu dari jumlah sampel yang sama, sehingga persentase kualitas air sungai yang memenuhi baku mutu mencapai 74\%. Pada tahun 2014 dan 2015, persentase kualitas air sungai yang memenuhi baku mutu turun cukup drastis ke angka sekitar 55\%. Hal ini karena dari sampel yang berjumlah 135, hanya sebanyak 75 dan 72 sampel yang memenuhi baku mutu. Pada tahun 2016, data juga tidak terlalu berubah signifikan, dengan persentase kualitas air sungai sesuai baku mutu naik menjadi 57,24\%. Hal ini memiliki arti bahwa telah terjadi penurunan persentase kualitas air sungai yang sesuai baku mutu yang juga menggambarkan semakin meningkatnya pencemaran air sungai. Masih banyak limbah padat rumah tangga maupun limbah cair industri yang dibuang ke sungai tanpa melalui proses pengolahan limbah terlebih dahulu. Kondisi ini tentu perlu menjadi perhatian pemerintah dan masyarakat mengingat sungai dapat menjadi sumber air baku yang potensial dikembangkan di masa depan mengingat kualitas dan kuantitas air tanah yang semakin menurun.

Certoma \& Notteboom (2015) memaparkan tentang program pelestarian lingkungan oleh pemerintah (top down) hanya bisa berjalan optimal jika didukung oleh pendekatan dari bawah (bottom-up) dalam bentuk gerakan sosial. Pendekatan dari gerakan akar rumput (grass root) sebagai bentuk peningkatan dalam pengelolaan lingkungan hidup sangat penting untuk dilakukan salah satunya melalui komunitas peduli lingkungan (David et al, 2016). Gerakan kewarganegaraan melalui komunitas masyarakat menjadi penyeimbang bagi kelompok-kelompok kepentingan lain sebagai upaya dalam menjaga ruang terbuka hijau milik publik sebagai wujud keadilan sosial yang biasanya berada di balik kebijakankebijakan pemerintah.

Berdasarkan latar belakang masalah di atas, maka dapat dirumuskan sebuah pertanyaan sebagai berikut: (1) bagaimana konsep penguatan kewarganegaraan ekologis untuk mewujudkan katahanan lingkungan di Kampung Hijau Kota Yogyakarta?; (2) bagaimana hasil dari penguatan kewarganegaraan ekologis untuk mewujudkan katahanan lingkungan di Kampung Hijau Kota Yogyakarta? dan (3) apa saja hambatan dalam penguatan kewarganegaraan ekologis untuk mewujudkan katahanan lingkungan di Kampung Hijau Kota Yogyakarta ?

Pola penelitian terkait dengan kewarganegaraan ekologis dan lingkungan yang menjadi objeknya di Kampung Hijau Kota Yogyakarta sebagaimana yang dilakukan di sini, merupakan pola penelitian yang telah cukup banyak dilakukan di Indonesia. Berdasarkan penelitian yang dilakukan oleh Fitriyani (2015) tentang peran pemuda dalam mengembangkan eco edu wisata mangrove dan implikasinya terhadap ketahanan daerah mengungkap bahwa pengembangan eco edu wisata mangrove ini berimplikasi terhadap ketahanan lingkungan daerah dengan indikator meliputi ketersediaan ekosistem, penggunaan energi yang minimal, pengendalian limbah dan pencemaran, kelanjutan sistem sosial budaya lokal, dan pemahaman konsep lingkungan hidup. Oleh karenanya, peran pemuda harus dilibatkan untuk menjaga 
Serlina Candra Wardina Sari, Samsuri, Darto Wahidin -- Penguatan Kewarganegaraan Ekologis Untuk Mewujudkan Ketahanan Lingkungan (Studi di Kampung Gambiran, Kelurahan Pandeyan, Kecamatan

Umbulharjo, Kota Yogyakarta, Daerah Istimewa Yogyakarta)

kelestarian lingkungan sehingga mempercepat proses pembangunan wilayah. Penelitian selanjutnya dilakukan oleh Kusumaningrum (2016) tentang aplikasi teori new social movement pada komunitas lingkungan di D.I Yogyakarta dan Bandung yang mengungkap bahwa pemerintah dapat menjadikan gerakan lingkungan sebagai embrio dalam mewujudkan partisipasi masyarakat dalam upaya implementasi kebijakan lingkungan.

Berdasarkan penelitian Nurmayanti (2017) tentang strategi Yayasan Mangrove Center Tuban dalam mengembangkan ecological citizenship pada masyarakat Tuban mengungkap bahwa strategi pengembangan ecological citizenship dalam masyarakat Tuban adalah terjalinnya hubungan baik antara manusia dan alam melalui kegiatan konservasi, kehidupan ekonomi masyarakat yang berwawasan lingkungan dan masyarakat memiliki kepedulian serta kesadaran terhadap hak dan kewajibannya dalam menjaga kelestarian lingkungan. Penelitian lain dilakukan oleh Nugroho dan Suharno (2017) tentang strategi pemerintah daerah dalam upaya penguatan ecological citizenship pada program Kota Tanpa Kumuh (KOTAKU) di Kabupaten Sukoharjo menunjukkan bahwa strategi pemerintah daerah Kabupaten Sukoharjo dalam upaya penguatan ecological citizenship melalui program KOTAKU direncanakan secara terpadu dengan menyelenggarakan dialog, sosialisasi, dan pelatihan untuk meningkatkan kapasitas atau partisipasi masyarakat dalam melestarikan daya dukung lingkungan.

Merujuk pada penelitian Nugroho, dkk (2017) tentang upaya peningkatan kompetensi profesional guru PPKn sekolah adiwiyata dalam pelaksanaan ecological citizenship menunjukkan bahwa dibuatnya kurikulum sekolah adiwiyata akan mengajarkan bagaimana hak dan kewajiban warga negara dalam melestarikan daya dukung lingkungan. Sekolah harus menyiapkan guru untuk melaksanakan kurikulum sekolah adiwiyata, dalam hal ini secara tidak langsung adalah guru sebagai pelaksana ecological citizenship di sekolah. Selanjutnya penelitian yang dilakukan oleh Swandana (2017) tentang peran komunitas pemuda bidang lingkungan dalam mewujudkan ketahanan lingkungan yang dilakukan pada komunitas Jogja Berkebun menunjukkan bahwa pemuda merupakan modal pembangunan yang memiliki semangat kerja dan idealisme yang tinggi serta generasi yang sedang mencari identitas. Pemuda perlu diarahkan pada kegiatan-kegiatan bersifat positif dan membangun. Komunitas Jogja Berkebun merupakan salah satu komunitas yang bergerak di bidang pelestarian daya dukung lingkungan. Meskipun demikian, penelitian tersebut umumnya tidak berlanjut pada upaya mendeskripsikan hasil penguatan kewarganegaraan ekologis terhadap ketahanan lingkungan. Maka upaya itulah yang dilakukan dalam penelitian ini, agar terjadi perbedaan (difference) dan kebaharuan (novelty) dengan penelitian sebelumnya.

Penelitian ini mengungkapkan kehadiran Kampung Hijau Kota Yogyakarta sebagai salah satu langkah nyata dalam upaya mengurangi kerusakan lingkungan maupun bencana alam dan sebagai bentuk ketahanan lingkungan di Kota Yogyakarta. Makna dari kampung hijau di sini bukan hanya sekedar sebuah kampung yang penuh dengan tumbuh-tumbuhan untuk penghijauan. Namun, secara lebih mendalam kampung hijau merupakan sebuah tekad "kembali ke alam", sehingga pengelolaan kampung mengarah pada aspek lingkungan. Dibalik itu semua, pengelolaan kampung ini 
diharapkan dapat meningkatkan kesejahteraan warganya. Indikator dalam kampung hijau yang ditetapkan Badan Lingkungan Hidup Kota Yogyakarta yaitu mengelola komponen biotik dan abiotik, serta pengelolaan komponen sosial, budaya, dan kesehatan masyarakat. Indikator ini lebih menonjolkan peran serta perangkat pemerintah desa atau kampung maupun masyarakat sebagai pilar penting dalam rangka penyelamatan lingkungan hidup di masa mendatang di Kota Yogyakarta.

Pelestarian alam dalam mewujudkan ketahanan lingkungan menjadi hal penting yang harus mendapat perhatian serius melalui penguatan kewarganegaraan ekologis yang berisi tentang hak warga negara dalam mendapatkan lingkungan yang bersih dan sehat tanpa melupakan kewajibannya untuk melestarikan lingkungan. Pada dunia pendidikan, penguatan bertujuan untuk memberikan informasi atau umpan balik bagi penerima atas perbuatannya sebagai suatu tindak dorongan ataupun koreksi. Penguatan segala bentuk respons, baik itu yang bersifat verbal maupun nonverbal (Usman, 2006: 80). Sejalan dengan hadiah atau hukuman adalah kedua respons yang memiliki tujuan yang sama, yaitu ingin mengubah tingkah laku seseorang. Definisi senada juga diberikan oleh Asril (2010: 77) yang menjelaskan bahwa penguatan merupakan respons terhadap tingkah laku positif yang dapat meningkatkan kemungkinan terulangnya kembali tingkah laku tersebut. Penguatan dapat diartikan sebagai suatu bentuk penghargaan, penghargaan ini tidak harus selalu berwujud materi, bisa juga dalam bentuk kata-kata, senyuman, anggukan, dan sentuhan. Penguatan (reinforcement) yang dilakukan komunitas melalui pemberian penghargaan (reward) secara tepat yang didasarkan pada prinsip-prinsip pengubahan tingkah laku. Dengan penguatan yang dilakukan komunitas, masyarakat akan semakin kaya dengan berbagai tingkah laku positif yang secara kumulatif dan sinergis menunjang keaktifan masyarakat dalam usaha mewujudkan ketahanan lingkungan.

Kajian mengenai kewarganegaraan ekologis adalah salah satu bidang dalam Pendidikan Pancasila dan Kewarganegaraan (PPKn) yang berfokus pada aspek hak dan kewajiban warga negara terhadap lingkungan. Hal ini erat kaitannya dengan nilai-nilai yang terkandung dalam dasar negara Indonesia yakni Pancasila. Secara ontologis, kesatuan sila-sila Pancasila sebagai suatu sistem bersifat hierarkis dan berbentuk piramidal yang terdiri dari: sila pertama, hakikat adanya Tuhan sebagai causa prima. Segala sesuatu yang ada termasuk manusia ada karena diciptakan Tuhan atau manusia ada sebagai akibat adanya Tuhan; sila kedua, manusia sebagai subjek pendukung pokok negara, karena negara adalah lembaga kemanusiaan, negara sebagai persekutuan hidup bersama yang anggotanya adalah manusia; sila ketiga, negara sebagai akibat adanya manusia yang bersatu; sila keempat, rakyat merupakan unsur negara di samping wilayah dan pemerintah. Rakyat sebagai totalitas individu-individu dalam negara yang bersatu; dan sila kelima, keadilan pada hakikatnya merupakan tujuan dalam menjalankan hidup bersama dalam masyarakat sosial (Kaelan, 2016: 11). Pancasila merupakan alat pemersatu dan penguat ketahanan nasional. Pancasila mendasari dibentuknya negara Indonesia dan dibangun sebagai gagasan atas keberagaman yang dimiliki oleh bangsa Indonesia (Maharani, Surono, Hadi, \& Ahmad, 2019).

Sejak disahkan secara konstitusional pada tanggal 18 Agustus 1945, Pancasila 
Serlina Candra Wardina Sari, Samsuri, Darto Wahidin -- Penguatan Kewarganegaraan Ekologis Untuk Mewujudkan Ketahanan Lingkungan (Studi di Kampung Gambiran, Kelurahan Pandeyan, Kecamatan

Umbulharjo, Kota Yogyakarta, Daerah Istimewa Yogyakarta)

adalah dasar (falsafah) negara, pandangan hidup, ideologi nasional, dan ligatur (pemersatu) dalam peri kehidupan kebangsaan dan kenegaraan Indonesia. Pancasila sebagai dasar statis yang mempersatukan sekaligus bintang penuntun yang dinamis, mengarahkan bangsa dalam mencapai tujuannya. Pancasila bermakna sebagai sumber jati diri, kepribadian, moralitas, dan haluan keselamatan bangsa (Latif, 2015: 41). Pada setiap sila-sila Pancasila memuat nilai-nilai yang terkandung di dalamnya, mulai dari nilai-nilai Ketuhanan, nilai-nilai Kemanusiaan, nilai-nilai Kesatuan, nilai-nilai Kerakyatan, dan nilai-nilai Keadilan. Kajian mengenai kewarganegaraan ekologis tidak tersurat secara langsung dalam kandungan nilai-nilai yang ada pada Pancasila. Kajian mengenai kewarganegaraan ekologis penting untuk digali lebih mendalam sebagai pedoman dalam menjalankan hak dan kewajiban manusia terhadap alam atau lingkungan sekitarnya. Lingkungan adalah salah satu aspek penting dalam menunjang kelangsungan hidup manusia tidak hanya untuk jangka waktu pendek namun juga dalam jangka waktu yang panjang. Oleh karena itu, gagasan kewarganegaraan ekologis hadir untuk menjadi pedoman manusia untuk bersikap terhadap alam guna menjaga keberlanjutan dari pelestarian daya dukung lingkungan yang ada.

Penguatan kewarganegaraan ekologis untuk mewujudkan ketahanan lingkungan memiliki makna mendalam bahwa kewarganegaraan ekologis sebagai hakikat dari warga negara yang peduli terhadap keberlangsungan lingkungan, melaksanakan kewajiban dalam bentuk pelestarian lingkungan sebelum mendapatkan hak atas lingkungan yang bersih dapat menjadi salah satu bentuk atau upaya untuk mewujudkan ketahanan lingkungan. Kewarganegaraan ekologis dipahami sebagai hak atas lingkungan yang tidak tercemar dan tanggung jawab untuk tidak merusak lingkungan serta berpartisipasi dalam pelestarian daya dukung lingkungan (Raessens, 2019: 101).

Kewarganegaraan ekologis telah banyak diperbincangkan dan menjadi salah satu topik utama dalam pembangunan berkelanjutan berbasis lingkungan hidup. Sebagaimana Curtin (2002: 296) tentang ecological citizenship bahwa gagasan kewarganegaraan ekologis sangat menjanjikan karena sesuai dengan pedoman bagaimana menjalani kehidupan secara utuh. Kewarganegaraan ekologis adalah suatu konsepsi yang menggambarkan hubungan manusia dengan lingkungan, terdapat unsur kesadaran dan kepedulian yang dituangkan dalam suatu bentuk aplikatif melalui kebiasaan dan kegiatan berbasis lingkungan. Salah satu wujud nyata penguatan kewarganegaraan ekologis telah ditunjukkan oleh Kampung Hijau Kota Yogyakarta. Konsep kampung hijau sudah mulai dilaksanakan salah satunya pada Kampung Gambiran yang telah dievaluasi Dinas Lingkungan Hidup (DLH) Yogyakarta. Kesadaran masyarakat akan lingkungan muncul karena dilatarbelakangi oleh bencana banjir dan kerusakan lingkungan yang disebabkan adanya limbah yang menumpuk. Bencana banjir dan limbah sampah tersebut membuat warga mengalami banyak kerugian. Oleh karena itu, peran serta masyarakat sebagai gerakan akar rumput membuat Kampung Hijau Kota Yogyakarta mencoba mengambil peran tersebut dengan menyelenggarakan program-program kepedulian lingkungan sejak tahun 2007.

Penelitian ini menggunakan pendekatan kualitatif dengan desain studi kasus untuk 
memaknai interaksi antara penggerak Kampung Hijau Kota Yogyakarta dengan realitas penguatan kepedulian warga negara di bidang lingkungan. Kampung Gambiran RT 45/RW 08 Kelurahan Pandeyan, Kecamatan Umbulharjo, Kota Yogyakarta dipilih sebagai lokasi penelitian karena merupakan lokasi pengembangan Kampung Hijau Kota Yogyakarta yang di dalamnya terdapat berbagai program-program kegiatan penguatan kewarganegaraan ekologis untuk mewujudkan ketahanan lingkungan.

Pengambilan data dilakukan melalui observasi, wawancara, dan dokumentasi terhadap informan dalam semua programprogram kegiatan penguatan kewarganegaraan ekologis untuk mewujudkan ketahanan lingkungan yang dilaksanakan di Kampung Hijau Kota Yogyakarta. Analisis data menggunakan teknik analisis interaktif yang terdiri dari reduksi data, penyajian data, dan verifikasi data (Miles \& Huberman, 2012). Data yang berhasil diperoleh kemudian divalidasi menggunakan teknik triangulasi sumber dan teknik dalam proses pengumpulan data.

\section{PEMBAHASAN}

\section{Konsep Penguatan Kewarganegaraan} Ekologis untuk Mewujudkan Ketahanan Lingkungan di Kampung Hijau, Gambiran, Kota Yogyakarta

Kampung Hijau Kota Yogyakarta terletak di Kampung Gambiran RT 45/RW 08, Kelurahan Pandeyan, Kecamatan Umbulharjo, Kota Yogyakarta. Pada tahun 2005-2006, Kampung Gambiran mengalami beberapa permasalahan lingkungan, seperti: bencana banjir karena lokasi Kampung Gambiran dibatasi jalan raya dan hampir separuh lokasi dikelilingi sungai Gajah Wong, serta limbah sampah yang menumpuk sehingga masyarakat resah terhadap kesehatan dan kebersihan lingkungan tempat mereka tinggal. Hal ini melatarbelakangi masyarakat untuk bangkit dari kerusakan lingkungan yang terjadi dan membuat beberapa kegiatankegiatan peduli lingkungan. Akhirnya pada tanggal 1 April 2007, masyarakat sepakat untuk mendeklarasikan Gambiran sebagai "Kampung Hijau Kota Yogyakarta”. Kampung Hijau Gajah Wong hingga saat ini sudah banyak melakukan kegiatan yang berhubungan dengan pengelolaan lingkungan, seperti: pengelolaan sampah terpadu, pembuatan IPAL (Instalasi Pengelohan Air Limbah), pembuatan taman, mural lingkungan, serta berbagai kegiatan penghijauan ramah lingkungan lainnya yang masih terus menerus dilakukan secara berkesinambungan (Rachmawati, 2015: 122).

Kewarganegaraan ekologis penting sebagai bekal masyarakat untuk menumbuhkan kesadaran dan kepedulian guna pelestarian alam dan lingkungan hidup secara berkelanjutan. Perubahan sikap yang berakar pada pertimbangan keadilan dan ketidakadilan pada bidang lingkungan mempromosikan bentuk gagasan kewarganegaraan yang peduli terhadap keberlangsungan lingkungan (Dobson, 2007: 276). Hal ini sejalan dengan Dash (2014: 27-37) bahwa kewarganegaraan ekologis berisi nilai-nilai moral yang memandu perilaku individu terhadap lingkungan dan pilihan untuk hidup damai dan bersahabat dengan bumi. Kewarganegaraan dalam definisi apapun selalu mengisyaratkan komitmen bagi kebaikan umum yakni bagi sebuah solidarita (Biehl, 2017: 145). Transformasi masyarakat yang berkelanjutan membutuhkan perubahan moral yang lebih dalam pada bidang lingkungan baik di tingkat individu 
Serlina Candra Wardina Sari, Samsuri, Darto Wahidin -- Penguatan Kewarganegaraan Ekologis Untuk Mewujudkan Ketahanan Lingkungan (Studi di Kampung Gambiran, Kelurahan Pandeyan, Kecamatan

Umbulharjo, Kota Yogyakarta, Daerah Istimewa Yogyakarta)

maupun kelompok masyarakat sebagai inti dari perwujudan ketahanan lingkungan secara berkelanjutan melalui pembangunan kampung hijau (Ardiyansari dkk, 2019).

Kampung hijau sebagai upaya untuk merubah dan memperbaiki lingkungan menjadi lebih baik dan asri. Hal ini merupakan solusi terbaik untuk mengatasi bencana daerah terkait kerusakan lingkungan demi mewujudkan lingkungan yang bersih dan sehat (Ikhtiar, 2016: 22). Salah satu contoh nyata sebagai upaya dalam penguatan kewarganegaraan ekologis sebagai wujud ketahanan lingkungan tergambar pada beberapa kegiatan yang digagas oleh Kampung Hijau Kota Yogyakarta sejak tahun 2007 hingga akhirnya pemerintah turut membantu pengelolaan Gambiran sebagai Kampung Hijau Kota Yogyakarta pada tahun 2010.

Pengelolaan sungai Gajah Wong menjadi ruang terbuka hijau dan taman edukasi. Kampung Hijau Kota Yogyakarta berada tepat di sekeliling jalan raya dan sungai Gajah Wong. Masyarakat menyadari bahwa bencana yang terjadi banyak disebabkan oleh perilaku masyarakat itu sendiri yang kurang peduli terhadap lingkungan. Bermula dari adanya bencana banjir dan lingkungan yang tercemar pada tahun 2005 sampai 2006 di Kampung Gambiran, memicu kesadaran dan inisiatif warga untuk merubah, mengelola, dan memperbaiki lingkungan yang rusak menjadi asri, bersih, dan terawat. Hal ini diawali dari kesadaran, tekad, dan kepedulian masyarakat terhadap pelestarian lingkungan tentunya tidak hanya dalam jangka waktu yang singkat namun berkelanjutan. Kesadaran masyarakat menimbulkan hubungan interaktif yang memunculkan beberapa ide untuk membuat kegiatan-kegiatan peduli lingkungan salah satunya pengelolaan sungai Gajah Wong.
Tujuan dari pengelolaan kebersihan sungai guna membentuk perilaku masyarakat dalam memperlakukan sungai sebagai bagian dari hunian yang harus dijaga.

Masyarakat Gambiran melakukan usaha penanggulangan banjir dan mengatasi penumpukan limbah dimulai dengan memasang bronjong sebagai penyangga banjir dan membersihkan limbah bersamasama agar lingkungan tidak terlihat kumuh dan membawa banyak sarang penyakit. Selain itu, masyarakat juga melakukan kegiatan penghijauan di daerah tepian sungai sebagai daerah resapan air dengan menanam beberapa tanaman produksi seperti buah dan sayur maupun tanaman hias untuk mengangkat potensi dan keindahan sungai (lihat Gambar $1)$.

Gambar 1

Pengelolaan Sungai Gajah Wong

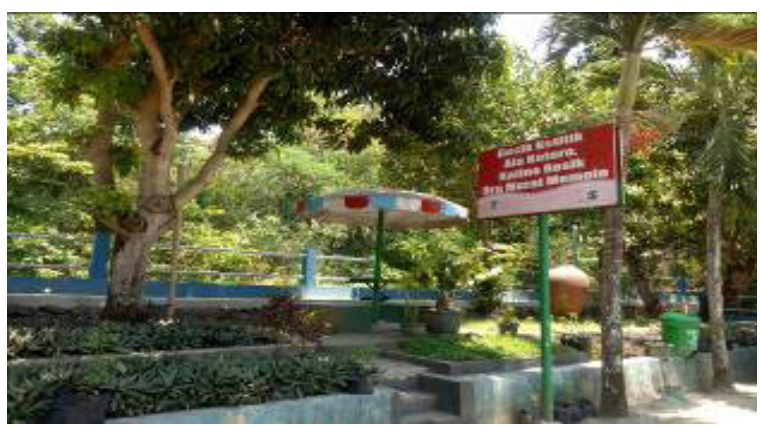

Sumber Dokumentasi: Peneliti, 2019

Usaha masyarakat sebagai bentuk kewarganegaraan ekologis untuk mewujudkan ketahanan lingkungan akhirnya berbuah manis. Pemerintah turut terlibat dalam pengelolaan sungai Gajah Wong pada tahun 2010 karena beberapa usaha dari penggerak atau aktivitas masyarakat Kampung Hijau Kota Yogyakarta. Pemerintah melakukan pengelolaan sungai Gajah Wong dengan mendirikan Gajah Wong Educational Park tepat disebelah sungai. Pembangunan taman edukasi sungai Gajah Wong dimulai pada tahun 2011 dan selesai pada 
tahun 2012. Respon masyarakat Kampung Gambiran sangat antusias karena program taman edukasi Gajah Wong sangat membantu dalam pengelolaan kebersihan lingkungan. Hal ini juga banyak menarik perhatian masyarakat luas seperti kunjungan masyarakat sebagai taman wisata, sosialisasi tentang lingkungan, serta kunjungan mahasiswa dan dosen untuk penelitian dan sharing terkait pengelolaan lingkungan, seperti: kampus UGM, UNDIP, UTY, dan UAD. Kunjungan tersebut tidak sebatas pada masyarakat dalam negeri namun juga masyarakat luar negeri, seperti dari Singapura dan Malaysia.

Pengelolaan taman edukasi Gajah Wong diberikan pada aktivis Kampung Hijau Kota Yogyakarta sebagai pelaku dominan dan pemerintah dalam hal ini Dinas Lingkungan Hidup (DLH) Kota Yogyakarta membantu dalam hal pemantauan setiap harinya. Taman Edukasi Gajah Wong memiliki beberapa fasilitas seperti area bermain anak-anak, Ruang Terbuka Hijau (RTH), pendopo, toilet, pemilahan sampah di setiap sisi sungai dan taman, serta track untuk melihat langsung sungai Gajah Wong. Masyarakat secara luas dapat mengunjungi taman edukasi Gajah Wong dengan gratis tanpa ada pungutan biaya. Masyarakat dapat melihat secara langsung terkait dengan pengembangan sungai Gajah Wong menjadi salah satu Ruang Terbuka Hijau dan pengelolaan lingkungan yang asri oleh masyarakat Kampung Gambiran yang berkolaborasi dengan pemerintah yakni DLH Kota Yogyakarta (lihat Gambar 2).

Kegiatan pelestarian lingkungan selanjutnya yakni tanam pohon. Kesadaran masyarakat Kampung Gambiran sebagai Kampung Hijau Kota Yogyakarta dapat menginspirasi masyarakat luas tentang upaya dalam melestarikan lingkungan hidup secara

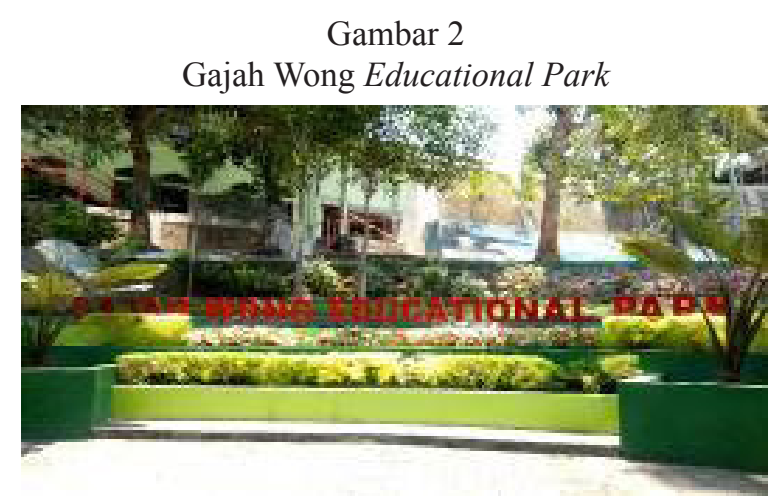

Sumber Dokumentasi: Peneliti, 2019

berkelanjutan. Pembangunan lingkungan secara berkelanjutan harus dimulai dari penguatan di tingkat lokal terlebih dahulu. Jika masyarakatnya tidak memiliki kesadaran dan kepedulian, maka akan sulit untuk bekerja sama dalam membangun lingkungan. Masyarakat Kampung Gambiran mengembangkan salah satu prinsip yakni pada penghijaun kampung dengan slogan "satu orang satu pohon". Slogan tersebut terbukti dengan hampir sebagian besar masyarakat memiliki tanaman di rumahnya.

Penghijauan melalui penanaman pohon juga dilakukan pada Ruang Terbuka Hijau (RTH) kampung sehingga suasana asri sangat terasa pada saat berkunjung di Kampung Gambiran. RTH Kampung Gambiran memiliki fungsi sebagai kebun bersama yang berupa tanaman produksi baik buah dan sayur yang dapat dipanen bersama serta tanaman hias sebagai potensi keindahan kampung. Selain itu, masyarakat juga memanfaatkan lahan kosong yang ada sebagai media tanah yang fungsional yakni berupa area publik dan area resapan air. Akses jalan di Kampung Gambiran sangat mudah dan terdapat track bagi pengunjung yang ingin melihat dan berkeliling kampung dengan suasana bersih dan asri (lihat Gambar 3).

Masyarakat Kampung Gambiran memiliki kesadaran terhadap pelestarian 
Serlina Candra Wardina Sari, Samsuri, Darto Wahidin -- Penguatan Kewarganegaraan Ekologis Untuk Mewujudkan Ketahanan Lingkungan (Studi di Kampung Gambiran, Kelurahan Pandeyan, Kecamatan Umbulharjo, Kota Yogyakarta, Daerah Istimewa Yogyakarta)

Gambar 3

Penanaman Pohon oleh Masyarakat

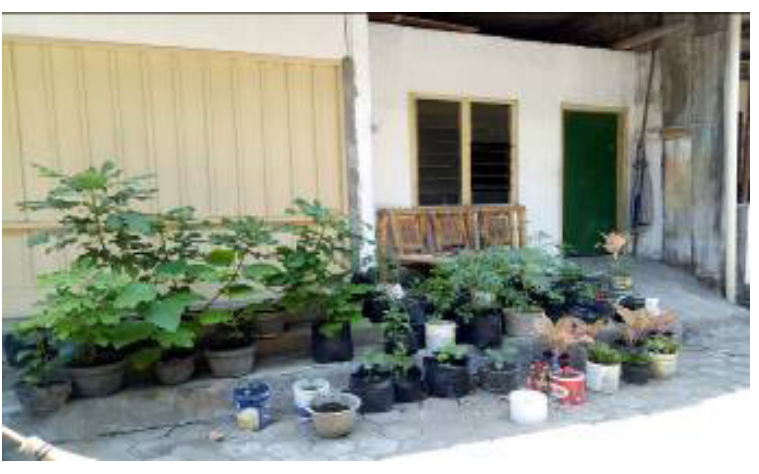

Sumber Dokumentasi: Peneliti, 2019

lingkungan guna keberlangsungan hidup pada masa sekarang dan masa yang akan datang. Sampah merupakan permasalahan yang mengganggu kesehatan lingkungan jika terus dibiarkan begitu saja tanpa adanya pengelolaan yang baik. Masyarakat Kampung Gambiran mengembangkan sistem pengelolaan sampah secara mandiri baik dari tingkat rumah tangga (hunian) sampai tingkat kelompok. Tujuan dari pengelolaan sampah mandiri untuk mengurangi masalah lingkungan yang timbul akibat sampah yang menumpuk. Pengelolaan sampah secara mandiri perlahan-lahan namun pasti terbentuk karena kesadaran masyarakat akan pentingnya menjaga lingkungan. Secara keseluruhan sampah yang dihasilkan dari tiap rumah tangga dikelola secara mandiri oleh masyarakat kampung.

Pengelolaan sampah mandiri dimulai dengan tahapan pertama yakni memilah sampah sesuai dengan kategorinya yaitu sampah organik dan non organik. Sampah non organik dapat dipilah menjadi lebih spesifik lagi yaitu sampah plastik, sampah logam/kaca, dan sampah kertas. Masyarakat diajak untuk terbiasa membuang sampah sesuai kategorinya dengan disediakan tempat sampah di beberapa titik daerah di Kampung Gambiran sehingga masyarakat lebih mudah dalam membiasakan pengelolaan sampah mandiri tersebut (lihat Gambar 4).

Gambar 4

Pemilahan Sampah Mandiri oleh Masyarakat

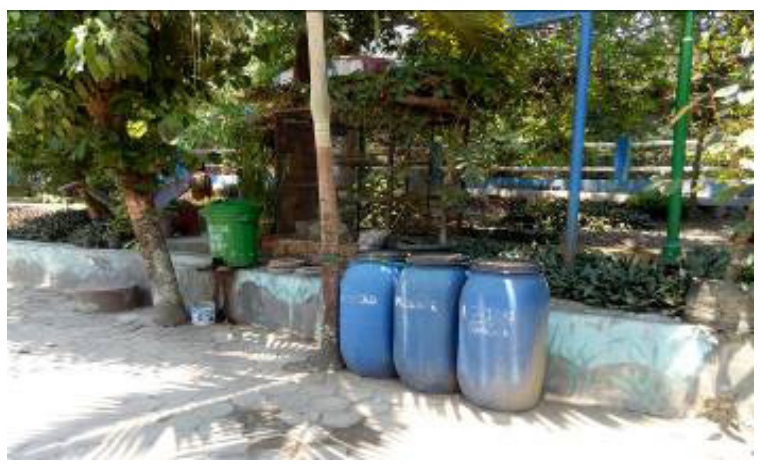

Sumber Dokumentasi: Peneliti, 2019

Masyarakat mengkategorikan sampah kembali sesuai dengan prinsip 3R (reduce atau mengurangi, reuse atau menggunakan kembali, recycle atau mendaur ulang). Tahapan ini dilakukan dan dipandu oleh pokja (kelompok kerja) bidang pengelolaan sampah sebelum akhirnya terbentuk bank sampah Kampung Gambiran. Pada prinsipnya bank sampah memiliki tujuan yang sama dengan pokja sampah, namun bank sampah memiliki nilai lebih untuk pengelolaan sampah di Kampung Gambiran. Tujuan dari bank sampah selain untuk membentuk kepedulian masyarakat agar sampah yang ada tidak dibuang begitu saja, sampah ternyata dapat ditabung dan memiliki nilai ekonomis jika diolah dengan benar. Nilai inilah yang mendukung masyarakat semangat dan antusias dalam mengolah sampah. Perilaku mengelola sampah juga didukung oleh pemerintah yang terus memantau Kampung Gambiran dan mengikutsertakan Kampung Gambiran pada program atau kegiatan penghargaan dalam bidang pengelolaan lingkungan.

Program pengelolaan bank sampah di Kampung Gambiran dilakukan dengan cukup 
sederhana. Setiap sampah yang ditabung masyarakat dihitung dan uangnya dapat digunakan untuk kegiatan kampung atau untuk masyarakat itu sendiri. Sampah yang disetor pada bank sampah berupa sampah non organik. Penyetoran sampah dilakukan dua kali setiap bulan saat kegiatan arisan berlangsung. Sampah yang telah disetor kemudian diserahkan ke pengepul atau diolah menjadi barang yang memiliki nilai ekonomis seperti kerajinan maupun digunakan sebagai elemen estetika (keindahan) Kampung Gambiran. Selain sampah non organik, sampah organik juga dikelola dengan baik oleh masyarakat Kampung Gambiran. Contoh dari sampah organik yakni daun, sisa makanan, sayur, dan kulit buah yang dikelola masyarakat menjadi kompos melalui komposer yang disebar di beberapa titik Kampung Gambiran. Kompos dapat dimanfaatkan masyarakat sebagai pupuk untuk menyuburkan tanaman yang telah ditanam oleh masyarakat (lihat Gambar 5).

Gambar 5

Komposer sebagai Pengolah Sampah Organik menjadi Kompos

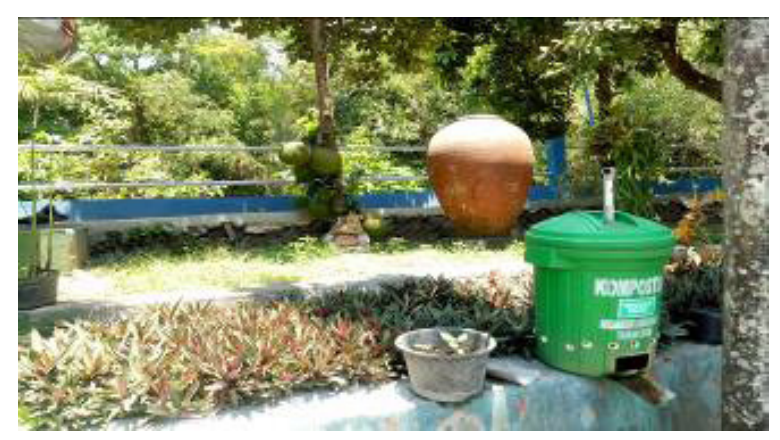

Sumber Dokumentasi: Peneliti, 2019

Kesadaran masyarakat Kampung Gambiran terhadap pentingnya lingkungan telah tersalurkan dengan beberapa contoh nyata kegiatan yang telah dilakukan. Kesadaran ini memicu kepedulian masyarakat untuk membentuk aksi peduli lingkungan. Masyarakat Kampung Gambiran mengembangkan sistem pengelolaan air limbah komunal yang ditempatkan di beberapa titik daerah sehingga dampak dari pencemaran air limbah khususnya limbah rumah tangga dapat diminimalisir sebelum air dibuang ke saluran air atau sungai. IPAL sangat membantu masyarakat Kampung Gambiran dalam menyaring limbah rumah tangga, sebagai contoh yakni limbah cuci yang mengandung bahan kimia dari deterjen yang dapat memengaruhi keasaman/pH tanah. Limbah dengan kandungan bahan kimia yang dibuang begitu saja ke sungai dapat mematikan tumbuhan dan hewan tertentu di sungai. Jika hal ini dibiarkan secara terus menerus dalam jangka waktu panjang, perlahan-lahan dapat merusak lingkungan secara keseluruhan. Oleh karena itu, IPAL penting dikelola secara berkelanjutan untuk menjaga kesehatan lingkungan (lihat Gambar 6).

\section{Gambar 6}

IPAL Komunal Kampung Gambiran

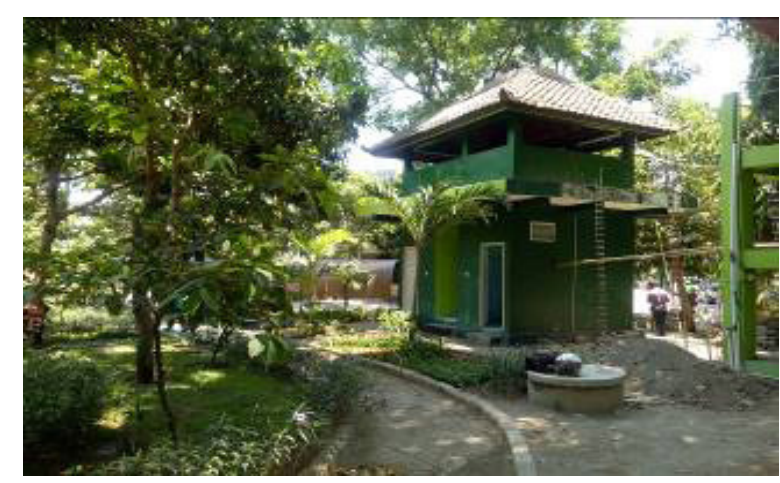

Sumber Dokumentasi: Peneliti, 2019

Ruang terbukahijaudi Kampung Gambiran sebagai Kampung Hijau Kota Yogyakarta berbentuk jalur dan area mengelompok yang penggunaannya lebih bersifat terbuka. RTH Kampung Gambiran dihiasi dengan tanaman baik yang tumbuh secara alami atau sengaja 
Serlina Candra Wardina Sari, Samsuri, Darto Wahidin -- Penguatan Kewarganegaraan Ekologis Untuk Mewujudkan Ketahanan Lingkungan (Studi di Kampung Gambiran, Kelurahan Pandeyan, Kecamatan

Umbulharjo, Kota Yogyakarta, Daerah Istimewa Yogyakarta)

di tanam. Tujuan dari penyediaan RTH untuk menjaga ketersediaan lahan sebagai daerah resapan air, menciptakan tata lingkungan daerah dan perkotaan yang memiliki nilai estetika melalui keseimbangan antara lingkungan alam dan lingkungan binaan yang berguna bagi kepentingan masyarakat bersama, serta meningkatkan keselarasan lingkungan yang aman, nyaman, asri, indah, dan bersih.

RTH memiliki beberapa fungsi yakni fungsi ekologis, fungsi sosial budaya, fungsi ekonomi, dan fungsi estetika. Fungsi ekologis tergambar melalui RTH sebagai paru-paru kota, pengatur iklim mikro, peneduh lingkungan, dan penyerap air hujan. Fungsi sosial budaya tergambar melalui RTH sebagai ekspresi budaya lokal, media komunikasi, dan tempat rekreasi atau hiburan masyarakat. Fungsi ekonomi tergambar melalui sumber produk yang memiliki nilai jual seperti tanaman bunga, buah, daun, dan sayur. Fungsi estetika dari RTH tergambar melalui peningkatan kenyamanan, memperindah lingkungan, menciptakan suasana yang asri dan bersih. Beberapa fungsi tersebut dapat dikombinasikan sesuai kebutuhan, kepentingan, dan keberlanjutan daerah masing-masing (lihat Gambar 7).

Gambar 7

Ruang Terbuka Hijau (RTH) Kampung Hijau Kota Yogyakarta

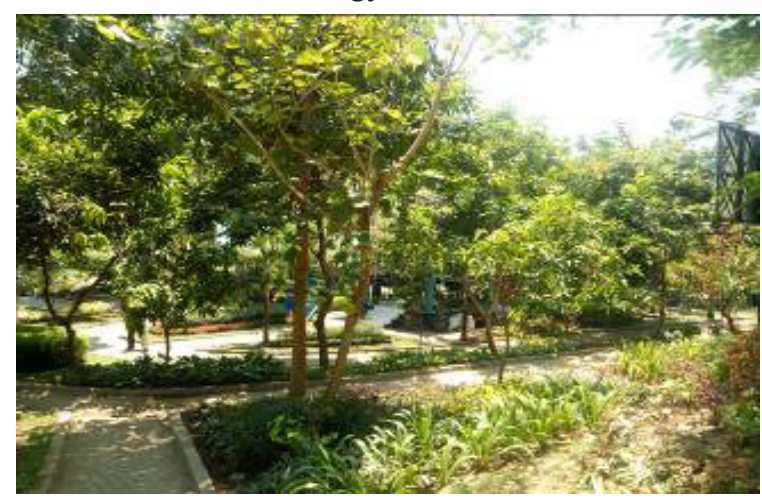

Sumber Dokumentasi: Peneliti, 2019
Kampung Gambiran mengelola beberapa taman edukasi yang memiliki banyak manfaat baik bagi masyarakat sekitar maupun pengunjung yang datang di Kampung Hijau Kota Yogyakarta. Taman Krida dan Taman Lintas Budaya merupakan contoh taman edukasi yang memiliki manfaat berbeda namun tetap memiliki ciri khas guna penguatan ketahanan lingkungan bagi masyarakat. Taman Krida merupakan taman yang dirancang guna memfasilitasi masyarakat dan pengunjung untuk berolahraga dengan suasana nyaman dan asri karena di sekitar taman banyak terdapat tanaman-tanaman dan pohon yang memiliki nilai ekologis dan nilai estetika dari taman tersebut. Taman Lintas Budaya yang berada di sebelah selatan Gajah Wong educational park memiliki fungsi untuk mewadahi acara-acara atau kegiatan yang berkaitan dengan pelestarian produk budaya Kota Yogyakarta. Terdapat pendopo untuk menampilkan tari-tarian daerah, jantilan, budaya legawong, pertunjukan wayang, dan berbagai kebudayaan Kota Yogyakarta yang lain. Acara seni dan budaya dilaksanakan setiap bulannya tergantung pada permintaan yang ada (lihat Gambar 8).

Gambar 8

Taman Krida dan Denah Menuju Taman Lintas Budaya

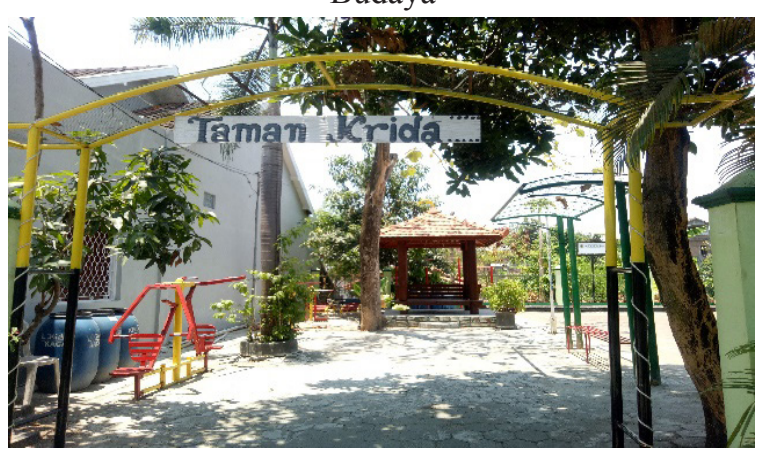

Sumber Dokumentasi: Peneliti, 2019

Anak-anak merupakan generasi penerus yang akan melanjutkan setiap usaha dan cita- 
cita masyarakat yang telah dirintis dari awal hingga berhasil dan berkelanjutan. Oleh karena itu, masyarakat Kampung Gambiran senantiasa memberikan edukasi dengan memfasilitasi berbagai sarana yang dibangun untuk anakanak belajar dan mendalami bagaimana hakikat pelestarian dan ketahanan lingkungan seperti taman wifi Gajah Wong dan perpustakaan kampung. Selain diisi dengan buku-buku pelajaran dan lingkungan, di sekitar perpustakaan juga dilengkapi dengan fasilitas-fasilitas yang mendukung konsep kampung hijau di antaranya: tempat pembuangan sampah, tempat pengumpulan barang-barang bekas, dan sistem pengolahan air. Program ini dilakukan agar anakanak terbiasa sejak dini memiliki perilaku peduli terhadap lingkungan seperti tidak membuang sampah sembarangan, membaca merupakan jendela ilmu, dan membiasakan diri untuk sadar terhadap keberlangsungan lingkungan. Selain itu, masyarakat Kampung Gambiran juga memasang beberapa tulisan penanda di dinding sebagai motivasi dan ajakan dalam melestarikan lingkungan. Taman wifi Gajah Wong diberikan untuk memberikan fasilitas pada masyarakat dan pengunjung agar tidak menjadi masyarakat yang tertinggal serta bisa mengakses beberapa informasi dengan cepat (lihat Gambar 9 dan Gambar 10).

Gambar 9

Perpustakaan Kampung Hijau Kota Yogyakarta

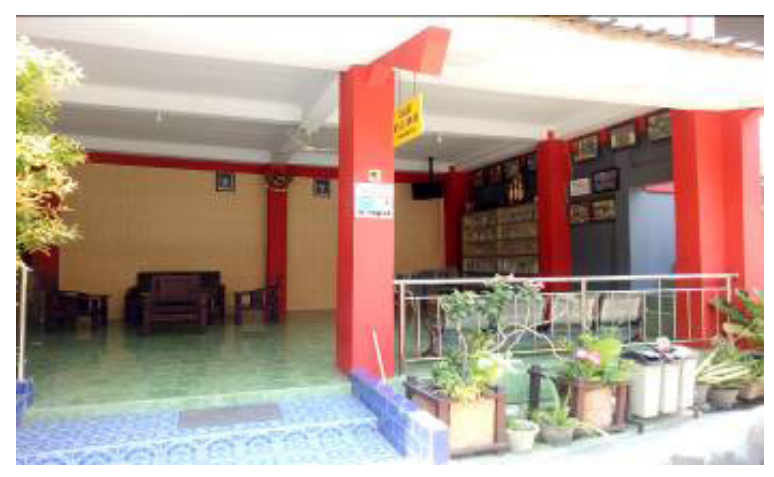

Sumber Dokumentasi: Peneliti, 2019
Gambar 10

Taman Wifi Gajah Wong

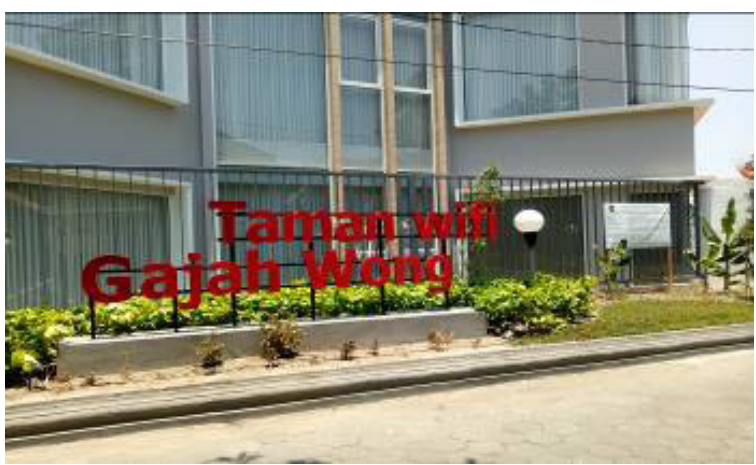

Sumber Dokumentasi: Peneliti, 2019

Penggunaan energi alternatif yang dilakukan oleh masyarakat Kampung Gambiran mengubah perilaku dengan menggunakan energi alami untuk digunakan pada kehidupan sehari-hari. Contoh nyata perwujudan dari penggunaan energi alternatif yang dijalankan adalah menggunakan energi matahari untuk lampu penerangan umum di malam hari. Selain itu, masyarakat juga mengolah air sumur dengan penyaringan sehingga dapat dimanfaatkan langsung sebagai air minum yang bersumber dari alam. Hal ini dilakukan oleh masyarakat untuk menciptakan fasilitas yang ramah akan lingkungan.

Penguatan kewarganegaraan ekologis melalui beragam kegiatan pelestarian lingkungan untuk mewujudkan ketahanan lingkungan telah dilaksanakan oleh Kampung Hijau Kota Yogyakarta. Hal ini sejalan dengan beberapa penelitian terdahulu seperti Nurmayanti (2017) bahwa strategi yayasan mangrove center Tuban dalam mengembangkan kewarganegaraan ekologis pada masyarakat Tuban dilaksanakan melalui program-program kerja yayasan yang meliputi konservasi dan pembibitan, pemberdayaan ecogreen dan pembinaan sekolah peduli lingkungan. Penelitian lain yang sejalan tentang penguatan kewarganegaraan ekologis 
Serlina Candra Wardina Sari, Samsuri, Darto Wahidin -- Penguatan Kewarganegaraan Ekologis Untuk Mewujudkan Ketahanan Lingkungan (Studi di Kampung Gambiran, Kelurahan Pandeyan, Kecamatan

Umbulharjo, Kota Yogyakarta, Daerah Istimewa Yogyakarta)

untuk mewujudkan ketahanan lingkungan juga diungkap oleh Ardiyansari dkk (2015) bahwa dalam mengembangkan usaha ekowisata kawasan konservasi mangrove Baros dalam mewujudkan ketahanan lingkungan meliputi tiga komponen yakni biotik, abiotik, dan kultur. Komponen biotik ditunjukkan dengan adanya aneka satwa yang singgah yakni mencari makan dan berkembang pada ekosistem Mangrove Baros. Komponen abiotik ditunjukkan melalui tindakan mencegah abrasi dan mencegah perembesan air payau ke sumur bor sebagai pengairan lahan pertanian. Komponen kultur ditunjukkan melalui pelestarian kearifan lokal yang dijadikan materi pembelajaran ekowisata. Penelitian yang dilakukan Nugroho dan Suharno (2017) bahwa upaya dalam penguatan kewarganegaraan ekologis untuk mewujudkan ketahanan lingkungan dijalankan melalui dialog interaktif, sosialisasi, dan pelatihan.

\section{Hasil Penguatan Kewarganegaraan Ekologis untuk Mewujudkan Ketahanan Lingkungan di Kampung Hijau, Gambiran, Kota Yogyakarta}

Masyarakat Kampung Gambiran telah melaksanakan beberapa kegiatan peduli lingkungan yang berakar dari gerakan atau inisiatif masyarakat sendiri hingga pada akhirnya pemerintah turut serta membantu dalam mengembangkan Kampung Gambiran sebagai Kampung Hijau Kota Yogyakarta. Kegiatan peduli lingkungan sebagai perwujudan ketahanan lingkungan telah menghasilkan beberapa kontribusi yang positif baik bagi masyarakat Kampung Gambiran maupun masyarakat luar yang berkunjung di Kampung Gambiran.

Hasil dari kewarganegaraan ekologis sebagai wujud dari ketahanan lingkungan, dengan melalui kegiatan yang telah dilakukan oleh Kampung Hijau Kota Yogyakarta membawa dampak positif pada beberapa bidang, salah satunya yakni bidang lingkungan. Tujuan utama dalam pengembangan Kampung Gambiran sebagai Kampung Hijau Kota Yogyakarta yakni mewujudkan lingkungan yang bersih, sehat, dan asri melalui kesadaran dan kepedulian masyarakat di tingkat lokal secara berkelanjutan. Tahapan pengelolaan Kampung Gambiran yang dilakukan secara transformatif dan runtut mulai dari inisiatif dan partisipasi masyarakat, kemitraan dan pengenalan melalui jejaring sosial telah membuka kesempatan berbagai pihak yang ingin berperan serta dalam pengembangan Kampung Gambiran sebagai tonggak dari Kampung Hijau Kota Yogyakarta yang akan disebar oleh pemerintah di 45 titik pada tingkat RW di Kota Yogyakarta. Kampung Gambiran memiliki luas wilayah yang paling luas yakni $5.000 \mathrm{~m}^{2}$ dan menjadi kampung pertama yang dikembangkan sebagai daerah pengembangan lingkungan dengan berbagai macam kegiatan peduli lingkungan yang dilakukan.

Penguatan kewarganegaraan ekologis sebagai wujud ketahanan lingkungan harus dimulai dari tingkat paling dasar yakni kesadaran dan kepedulian individu dan kelompok terhadap pentingnya melestarikan lingkungan. Wujud dari kesadaran dan kepedulian tersebut adalah sikap peduli lingkungan sebagai bentuk partisipasi dalam beberapa kegiatan peduli lingkungan. Sikap peduli terhadap lingkungan berarti turut serta melestarikan lingkungan hidup dengan sebaikbaiknya, dengan cara memelihara, mengelola, memulihkan, serta menjaga lingkungan hidup. Sikap peduli lingkungan sebagai wujud ketahanan lingkungan harus berpedoman dalam beberapa hal, yakni: menghindarkan dan menyelamatkan sumber bumi dari 
pencemaran dan kerusakan; menghindari tindakan-tindakan yang dapat menimbulkan pencemaran, merusak kesehatan, dan lingkungan; memanfaatkan sumber daya alam yang renewable atau yang tidak dapat diganti dengan sebaik-baiknya; memelihara dan memperbaiki lingkungan untuk generasi mendatang.

Langkah praktis yang dapat dilakukan untuk membangun kesadaran dan kepedulian masyarakat terhadap lingkungan, yakni: (1) dimulai dan biasakan dari kehidupan keseharian individu dalam masyarakat; (2) penguatan sikap peduli lingkungan dari keluarga berupa contoh perlakuan positif yang berdampak pada pelestarian lingkungan seperti membiasakan tidak membuang sampah sembarangan, memilah sampah sesuai kategorinya, dan mengikuti kegiatan kerja bakti kampung bersama setiap minggu pagi; (3) kerja sama dengan pihak pendidikan untuk penguatan kepedulian lingkungan dengan metode habituasi di lingkungan sekolah. Lingkungan di mana individu tinggal membawa pengaruh signifikan pada pembiasaan individu dalam kehidupan sehari-harinya. Oleh karena itu, penguatan kewarganegaraan ekologis sebagai wujud ketahanan lingkungan harus didukung oleh semua pihak agar tercipta pembiasaan sikap peduli terhadap lingkungan yang konsisten.

Kampung Gambiran sebagai Kampung Hijau Kota Yogyakarta tidak hanya memberikan hasil positif dalam bidang lingkungan namun juga pada bidang sosial. Kemajuan dalam pembangunan Kampung Gambiran yang bekerja sama dengan pemerintah dalam hal ini DLH Kota Yogyakarta menunjukkan perubahan yang signifikan terhadap tanah hunian masyarakat yang menjadi lebih bersih, asri, dan tertata dengan baik. Bermula dari permasalahan lingkungan yang meresahkan masyarakat yakni banjir, limbah sampah menumpuk, dan lingkungan yang kotor membuat masyarakat melalukan musyawarah desa atau rembug desa dalam membahas solusi atau tindakan yang hendak dilakukan dalam menanggapi permasalahan lingkungan yang terjadi. Terjalin kesepakatan bersama dalam satu tujuan yakni bersama-sama membangun dan memperbaiki lingkungan sekitar agar terhindar dari lingkungan yang rusak, kotor, dan membawa banyak sarang penyakit.

Masyarakat Kampung Gambiran sepakat bahwa dalam melangsungkan hidup yang damai harus memiliki tiga prinsip arah hidup yang menjadi pegangan, yakni: hubungan antara manusia dengan Sang Pencipta; hubungan manusia dengan manusia lainnya; serta hubungan manusia dengan lingkungannya. Ketiga arah hubungan harus menjadi pedoman dalam menjalankan kehidupan agar tercapai keselarasan hidup yang harmonis. Kampung Hijau Kota Yogyakarta menjadi wadah atau perkumpulan masyarakat Kampung Gambiran yang peduli terhadap lingkungannya. Hal ini membawa hasil positif pada keseharian masyarakat yang kompak dan menciptakan hubungan interaktif dalam melaksanakan kegiatan atau program yang telah disepakati untuk mengembangkan Kampung Gambiran menjadi pioner atau daerah percontohan yang ramah lingkungan dan berkelanjutan.

Selama perjalanannya Kampung Hijau sejak didirikan hingga saat ini yang dilakukan oleh para aktivis dan masyarakat di Kampung Gambiran Kota Yogyakarta telah mendapatkan beberapa penghargaan atau prestasi yang membanggakan (lihat Tabel 1).

Masyarakat Kampung Gambiran sangat memperhatikan perkembangan setiap kegiatan yang dilakukan dengan prinsip gotong royong 
Serlina Candra Wardina Sari, Samsuri, Darto Wahidin -- Penguatan Kewarganegaraan Ekologis Untuk Mewujudkan Ketahanan Lingkungan (Studi di Kampung Gambiran, Kelurahan Pandeyan, Kecamatan Umbulharjo, Kota Yogyakarta, Daerah Istimewa Yogyakarta)

Tabel 1

Prestasi Kampung Hijau Kota Yogyakarta

\begin{tabular}{ccl}
\hline No. & Tahun & \\
\hline 1. & 2007 & Juara Lomba Kampung Hijau Tingkat Provinsi DIY \\
2. & 2008 & Juara Umum Kali Bersih Kota Yogyakarta \\
3. & 2008 & Juara Green and Clean Provinsi DIY \\
4. & 2009 & Juara Walikota Award Pengelolaan Ruang Terbuka Hijau \\
5. & 2012 & Rintisan ProKlim (Program Kampung Iklim) Kementerian Lingkungan Hidup \\
6. & 2012 & Kampung Gambiran dapat meluaskan kiprah Gerakan lingkungan dengan membentuk Gajah \\
& & Wong Educational Park dan melaksanakan ritual merti Kampung Gambiran \\
7. & 2013 & Juara Indonesia MDG's Award \\
\hline
\end{tabular}

Sumber Dokumentasi: Data Penghargaan Kampung Gambiran, 2019

demi mewujudkan ketahanan lingkungan sebagai Kampung Hijau Kota Yogyakarta. Selain menghasilkan kontribusi dalam bidang lingkungan dan sosial, Kampung Gambiran juga memberikan hasil positif dalam bidang ekonomi. Kampung Gambiran terletak tepat di sekelilimg Sungai Gajah Wong yang sekarang sudah menjadi Gajah Wong educational park sehingga dapat memberikan kesempatan kepada masyarakat dalam mendirikan toko atau warung-warung kecil untuk dijajakan pada masyarakat dan pengunjung yang datang. Hasil olahan sampah yang menjadi kerajinan dapat dijual pada pengunjung sebagai buah tangan saat berkunjung di Kampung Hijau Kota Yogyakarta. Pengembangan Kampung Gambiran sebagai Kampung Hijau Kota Yogyakarta harus didukung oleh seluruh masyarakat agar program atau kegiatan sebagai usaha pembangunan kampung dapat berjalan sesuai dengan tujuan bersama yakni kesejahteraan masyarakat kampung.

\section{Hambatan dalam Penguatan Kewarga- negaraan Ekologis untuk Mewujudkan Ketahanan Lingkungan di Kampung Hijau, Gambiran, Kota Yogyakarta}

Keberhasilan dalam sebuah program atau kegiatan tidak selalu berjalan dengan lancar tanpa hambatan atau tantangan. Tantangan dan hambatan dalam menjalankan gerakan pro lingkungan terkait dengan masalah (problem) kepedulian. Kepedulian berbeda dengan kesadaran, tidak semua individu yang memiliki kesadaran terhadap lingkungan peduli akan keberlangsungan lingkungan. Namun individu yang peduli terhadap lingkungan pasti memiliki kesadaran yang kuat bahwa sebagai manusia harus menjaga hubungan baik dengan lingkungan. Contoh nyata dalam hal membuang sampah sembarangan sangat merugikan lingkungan dan jika dibiarkan secara terus menerus dapat menimbulkan kerusakan dan bencana seperti banjir. Bagi orang yang peduli dengan lingkungan, membuang sampah pada tempatnya sudah menjadi keharusan dan kebiasaan yang didukung dengan kesadaran yang kuat. Namun bagi orang yang hanya sadar bahwa membuang sampah sembarangan membawa dampak negatif, orang tersebut bisa saja menjadi bagian dari pelaku negatif tersebut dan masih membuang sampah sembarangan.

Faktor penghambat dalam penumbuhan kewarganegaraan ekologis telah diidentifikasi oleh Dobson (2007: 283) diantaranya: perilaku yang mementingkan diri sendiri, tidak akan selalu melindungi atau mempertahankan barang publik seperti lingkungan; kewarganegaraan selalu menjadi masalah keseimbangan antara hak dan tanggung jawab; serta manusia 
memanfaatkan lingkungan demi keberlanjutan hidup namun terkadang sering melupakan tanggung jawab dalam menjaga pelestarian daya dukung lingkungan. Misalnya budaya menebang pohon untuk pembuatan perabot rumah tangga yang tidak diimbangi dengan kegiatan tanam kembali. Warga lingkungan memiliki tanggung jawab untuk bekerja menuju masyarakat yang berkelanjutan, hal ini mencakup semua program kegiatan yang bersangkutan dengan kewarganegaraan ekologis yang baik, seperti: daur ulang, penggunaan kembali, dan pelestarian daya dukung lingkungan hidup.

Kesadaran masyarakat sebagai bentuk kewarganegaraan ekologis di mana masyarakat wajib menjaga lingkungan dan berhak menikmati lingkungan yang bersih merupakan suatu perwujudan dari ketahanan lingkungan. Letak tantangan dan hambatan dalam pengembangan Kampung Gambiran sebagai Kampung Hijau Kota Yogyakarta pada kepedulian masyarakat yang terkadang naik turun dan peran pemuda yang masih kurang sehingga menghambat proses regenerasi. Kebanyakan para generasi muda di Kampung Gambiran ada yang kuliah di luar daerah, kerja di luar daerah, dan tidak kembali ke kampung, serta nikah dapat orang luar daerah. Oleh karena itu, proses regenerasi disini menjadi tantangan sekaligus hambatan dalam pengembangan Kampung Hijau Kota Yogyakarta secara berkelanjutan.

Tantangan yang tidak kalah penting dalam pembangunan Kampung Gambiran secara berkelanjutan melalui penguatan nilai-nilai peduli lingkungan di tingkat lokal atau masyarakat sebagai fondasi dasar dalam mempertahankan apa yang telah diraih atau dilakukan. Kerja sama antara masyarakat dan pemerintah tergambar secara harmonis dalam pengembangan Kampung Hijau Kota Yogyakarta karena masyarakat memiliki semangat untuk mengelola lingkungan dan pemerintah membantu serta memberikan fasilitas berupa dana dan bantuan fisik yang mendukung kegiatan pro lingkungan di Kampung Gambiran. Hal yang menjadi perhatian serius bagi masyarakat dan pemerintah untuk mencegah munculnya oknum-oknum atau perkumpulan masyarakat yang mengambil untung secara pribadi dalam pengembangan Kampung Hijau Kota Yogyakarta seperti pungli (pungutan liar), penyelewengan dana yang tidak bertanggungjawab, dan pencemaran nama baik. Oleh karena itu, sinergi atau hubungan antara masyarakat dan pemerintah harus secara terbuka dan interaktif guna penguatan kewarganegaraan ekologis dalam mewujudkan ketahanan lingkungan di Kampung Gambiran.

Penelitian yang dilakukan oleh Nurmayanti (2017) menunjukkan hal yang sama bahwa salah satu faktor penghambat dalam penguatan kewarganegaraan ekologis untuk mewujudkan ketahanan lingkungan berasal dari tingkat partisipasi masyarakat yang kurang stabil (naik-turun). Oleh karena itu, sinergi antara seluruh lapisan masyarakat sangat diperlukan dalam upaya pelestarian alam guna mewujudkan ketahanan lingkungan. Penelitian lain yang mengungkap tentang faktor penghambat dalam penguatan kewarganegaraan ekologis untuk mewujudkan ketahanan lingkungan dalam bidang pendidikan memiliki beberapa permasalahan yang dihadapi yakni kurangnya persiapan dan pendampingan oleh dinas terkait serta waktu pembelajaran dan keterkaitan dengan materi pembelajaran yang diberikan kepada siswa dalam melaksanakan pendidikan berwawasan lingkungan melalui program 
Serlina Candra Wardina Sari, Samsuri, Darto Wahidin -- Penguatan Kewarganegaraan Ekologis Untuk Mewujudkan Ketahanan Lingkungan (Studi di Kampung Gambiran, Kelurahan Pandeyan, Kecamatan

Umbulharjo, Kota Yogyakarta, Daerah Istimewa Yogyakarta)

adiwiyata (Nugroho dkk, 2017). Sinergi antara masyarakat dan pemerintah juga diungkapkan oleh Nugroho dan Suharno (2017) melalui penelitian pada program Kota Tanpa Kumuh (KOTAKU) di Kabupaten Sukoharjo. Pada tingkat partisipasi masyarakat belum sepenuhnya mendukung karena kesibukan masing-masing individu yang berbeda. Oleh karena itu, sinergi dari semua pihak sangat diharapkan demi keberlangsungan setiap program atau kegiatan yang akan dilaksanakan.

\section{SIMPULAN}

Kewarganegaraan ekologis merupakan gagasan yang membawa implikasi penting dalam upaya pelestarian lingkungan guna menciptakan ketahanan lingkungan. Kesadaran masyarakat sebagai bentuk kewarganegaraan ekologis di mana masyarakat wajib menjaga lingkungan dan berhak menikmati lingkungan yang bersih merupakan suatu perwujudan dari ketahanan lingkungan. Salah satu bentuk wujud nyata pelestarian lingkungan guna mewujudkan ketahanan lingkungan telah dilakukan oleh Kampung Gambiran sebagai Kampung Hijau Kota Yogyakarta melalui berbagai program-program kegiatan pelestarian lingkungan yakni: pengelolaan sungai Gajah Wong, tanam pohon, pengelolaan sampah mandiri, Instalasi Pengolahan Air Limbah (IPAL) komunal, Ruang Terbuka Hijau (RTH), taman krida dan taman lintas budaya, perpustakaan dan taman wifi, serta penggunaan energi alternatif.

Program-program kegiatan pelestarian lingkungan membawa dampak atau hasil positif tidak hanya pada bidang lingkungan, namun juga pada bidang sosial dan ekonomi masyarakat Kampung Hijau Kota Yogyakarta. Melihat sisi lain dari hasil yang telah dicapai, penguatan kewarganegaran ekologis guna mewujudkan ketahanan lingkungan di Kampung Hijau Kota Yogyakarta juga memiliki tantangan dan hambatan yang terletak pada kepedulian masyarakat yang terkadang naik turun dan peran pemuda yang masih kurang sehingga menghambat proses regenerasi. Oleh karena itu, sinergi antara masyarakat dan pemerintah harus secara terbuka dan interaktif dalam mewujudkan ketahanan lingkungan di Kampung Gambiran secara berkelanjutan.

Berdasarkan hasil uraian di atas maka dapat direkomendasikan beberapa hal sebagai berikut. (1) pemerintah hendaknya mengakomodir seluruh lapisan masyarakat agar tergerak dalam upaya penguatan kewarganegaraan ekologis untuk mewujudkan ketahanan lingkungan di Kampung Hijau Kota Yogyakarta; (2) dari segi masyarakat hendaknya lebih intens dalam berpartisipasi pada kegiatan-kegiatan yang dilaksanakan sebagai upaya penguatan kewarganegaraan ekologis untuk mewujudkan ketahanan lingkungan di Kampung Hijau Kota Yogyakarta; (3) diperlukan penyebarluasan terkait dengan penghijauan dan dapat ditambahkan wisata edukasi dan kunjungan agar dapat melakukan interaksi dalam membahas topik-topik pelestarian lingkungan secara berkelanjutan.

\section{DAFTAR PUSTAKA}

Ardiyansari, N., Saryani, S., \& Muhamad, M 2019, 'Peran Organisasi Pemuda dalam Pengembangan Ekowisata Kawasan Mangrove Guna Mewujudkan Ketahanan Lingkungan (Studi pada Keluarga Pemuda Pemudi Baros (KP2B) di Dusun Baros, Desa Tirtohargo, Kecamatan Kretek, Kabupaten Bantul, 
Daerah Istimewa Yogyakarta)', Jurnal Ketahanan Nasional, vol. 25, no. 2, hh. 226-252.

Asril, Z 2010, 'Micro Teaching: Disertai dengan Pedoman Pengalaman Lapangan', Jakarta: Rajawali Press.

Biehl, Janet, 2017, 'Politik Ekologi Sosial: Munisipalisme Libertarian', Tanpa Kota: Daun Malam.

Budimansyah, D 2015, 'Fundamental Sociological Symptoms as a Source of Occurrence of Turbulence Indonesian Society During the Post-Reform'. Proceedings of the $1^{\text {st }}$ UPI International Conference on Sociology Education, Universitas Pendidikan Indonesia, Bandung, 12 Oktober 2015, hh. 63-66.

Certoma, C., \& Notteboom, B 2015, 'Informal Planning in a Transactive Governmentality: Re-Reading Planning Practices Through Ghent's Community Gardens', Journal of Planning Theory, vol. 16, no. 1, hh. 1-24.

Dash, A 2014, 'International Review of Sociology: Revue Internationale de Sociologie: the Moral Basis of Sustainable Society: the Gandhian Concept of Ecological Citizenship', International Review of Sociology, vol. 24, no. 1. hh. 37-41.

David, I. W., F. Guillaurne, B., Robert, O., Otso, O., Sara, T., Steven, C. W., \& Francis, K. C. H 2016, 'Extending Joint Models in Community Ecology: A Response to Beissinger et al', Trends in Ecology \& Evolution, vol. 31, no. 10, hh. 737-738.

Dobson, A 2007, 'Environmental Citizenship: Towards Sustainable Development', Journal Sustainable Development, vol. 15, hh. 276-285.
Fitriyani 2015, 'Peran Pemuda dalam Mengembangkan Eco Edu Wisata Mangrove dan Implikasinya terhadap Ketahanan Lingkungan Daerah (Studi pada Perkumpulan Pemuda Peduli Lingkungan "Prenjak" Dusun Tapak, Kelurahan Tugurejo, Kecamatan Tugu, Kota Semarang, Provinsi Jawa Tengah)', Jurnal Ketahanan Nasional, vol. 21, no. 2, hh. 137-157.

Foster, John Bellamy, 2013, 'Ekologi Marx: Materialisme dan Alam', Jakarta: Wahana Lingkungan Hidup Indonesia (WALHI) dan Aliansi Pemuda Progresif. Ikhtiar, M 2016, 'Pencemaran dan Strategi Penanggulangannya' Makasar: CV. Social Politic Genius (SIGn).

Irwan, Z. D 2017, 'Prinsip-Prinsip Ekologi: Ekosistem, Lingkungan dan Pelestariannya'. Jakarta: PT. Bumi Aksara.

Jannah, R 2018, "Menciptakan Kewarganegaraan Ekologis di Era Digital Melalui Kampoeng Recycle Jember', Jurnal of Urban Sociology, vol. 1, no. 2, hh. 14-26.

Kalidjernih, F. K 2011, 'Puspa Ragam Konsep dan Isu Kewarganegaraan’. Edisi Ketiga. Bandung: Widya Aksara Press. Kusumaningrum, H 2016, 'Aplikasi Teori New Social Movement pada Komunitas Lingkungan di D. I Yogyakarta dan Bandung', Tesis, Universitas Gadjah Mada.

Mariyani. 2017, 'Strategi Pembentukan Kewarganegaraan Ekologis', Prosiding Konferensi Nasional Kewarganegaraan III, Universitas Ahmad Dahlan, Yogyakarta, 11 November 2017, hh. 10-17. Miles, M. B., \& Huberman, A. M 2012, 'Analisis Data Kualitatif: Buku Sumber 
Serlina Candra Wardina Sari, Samsuri, Darto Wahidin -- Penguatan Kewarganegaraan Ekologis Untuk Mewujudkan Ketahanan Lingkungan (Studi di Kampung Gambiran, Kelurahan Pandeyan, Kecamatan Umbulharjo, Kota Yogyakarta, Daerah Istimewa Yogyakarta)

tentang Metode-Metode Baru'. Jakarta:

Universitas Indonesia Press.

Nagra, V., 2010, 'Environmental Education Awareness among School Teachers', The Environmentalist, vol. 30, no. 2, hh. 153-162.

Nugroho, Dedy Ari dan Suharno 2017, 'Strategi Pemerintah Daerah dalam Upaya Penguatan Ecological Citizenship pada Program Kota Tanpa Kumuh (Kotaku) di Kabupaten Sukoharjo', Jurnal PKn Progresif, vol. 12 no. 2, hh. 663-674.

Nugroho, Intan Ari, Triyanto, dan Triana Rejekiningsih 2017, 'Upaya Peningkatan Kompetensi Profesional Guru Sekolah Adiwiyata dalam Pelaksanaan Ecological Citizenship (Studi di SMA Negeri 4 Surakarta)', Jurnal PKn Progresif, vol. 12, no. 2, hh. 634-648.

Nurhasnawati 2005, 'Strategi Pembelajaran Mikro', Pekanbaru: Fakultas Tarbiyah dan Keguruan IAIN Sultan Syarif Kasim Riau Pekanbaru.

Nurmayanti, I 2017, 'Strategi Yayasan Mangrove Center Tuban dalam Mengembangkan Ecological Citizenship pada Masyarakat Tuban', Jurnal Kajian Moral dan Kewarganegaraan, vol. 05, no. 02, hh. 83-97.

Peraturan Daerah Kota Yogyakarta Nomor 11 Tahun 2017, 'Rencana Pembangunan Jangka Menengah Daerah (RPJMD) Kota Yogyakarta Tahun 2017-2022'. https:// bappedajogjakota.wordpress.com/rpjmd/.

Pertiwi, S., \& Samsuri 2017, 'Pembentukan Kompetensi Ekologis dengan Model
Pembelajaran Kontekstual dan Berbasis Masalah dalam PPKn di SMP', Jurnal Civics, vol. 14, no. 2, hh. 154-165.

Prasetyo, W. H., \& Dasim, B 2016, 'Warga Negara dan Ekologi: Studi Kasus Pengembangan Warga Negara Peduli Lingkungan dalam Komunitas Bandung Berkebun', Jurnal Pendidikan Humaniora, vol. 4, no. 4, hh. 177-186. Prayitno 2009, 'Dasar Teori dan Praksis Pendidikan', Jakarta: PT Gramedia Widiasarana Indonesia.

Rachmawati, Rini, 2015, 'Komunitas Kampung Hijau di Kota Yogyakarta: Implementasi Education for Sustainable Development dalam Mata Kuliah Manajemen Perkotaan di Fakultas Geografi dalam buku Merajut Pengalaman Pendidikan untuk Pembangunan Berkelanjutan Universitas Gadjah Mada,'Yogyakarta: Gadjah Mada University Press.

Swandana, I 2017, 'Peran Komunitas Pemuda Bidang Lingkungan dalam Mewujudkan Ketahanan Lingkungan (Studi pada Komunitas Jogja Berkebun, Yogyakarta', Tesis, Universitas Gadjah Mada.

Usman, M., U 2006, 'Menjadi Guru Professional', Bandung: PT Remaja Rosdakarya.

Yuniarto, B 2011, 'Membangun Kesadaran Warga Negara untuk Pelestarian Lingkungan (Penelitian Grounded Theory dalam Konteks Ekologi Kewarganegaraan)', Disertasi, (online). http://repository.upi.edu/7789/. 